\title{
Spatial Distribution of Hemlock Woolly Adelgid Induced Hemlock Mortality in the Southern Appalachians
}

\author{
Tuula Kantola1, Päivi Lyytikäinen-Saarenmaa ${ }^{2}$, Robert N. Coulson'1, Sheryl Strauch ${ }^{1}$, \\ Maria D. Tchakerian1, Markus Holopainen², Hannu Saarenmaa ${ }^{3}$, Douglas A. Streett ${ }^{4}$ \\ ${ }^{1}$ Knowledge Engineering Laboratory, Department of Entomology, Texas A \& M University, College Station, \\ TX, USA \\ ${ }^{2}$ Department of Forest Sciences, University of Helsinki, Helsinki, Finland \\ ${ }^{3}$ SIB Labs, School of Computing, University of Eastern Finland, Joensuu, Finland \\ ${ }^{4}$ Alexandria Forestry Center, USDA Forest Service, Southern Research Station, Pineville, LA, USA \\ Email: tuula.kantola@helsinki.fi
}

Received 16 August 2014; revised 18 September 2014; accepted 29 September 2014

Copyright (C) 2014 by authors and Scientific Research Publishing Inc.

This work is licensed under the Creative Commons Attribution International License (CC BY).

http://creativecommons.org/licenses/by/4.0/

(c) (i) Open Access

\section{Abstract}

Hemlock woolly adelgid (Adelges tsugae Annand, HWA) outbreaks are posing a major threat to eastern hemlock (Tsuga canadensis L. Carr.) and Carolina hemlock (Tsuga caroliniana Engelm.) forest landscapes in the eastern USA. As foundation species, hemlocks play a variety of functional roles in forest landscapes. These species usually occur as isolated canopies and mixed species in landscapes where variation in topography is extreme. Spatially explicit inventory information on HWA induced hemlock mortality at landscape scale does not exist. High resolution aerial imageries enable landscape scale assessment even at the individual tree level. Accordingly, our goal was to investigate spatial pattern and distribution of HWA induced hemlock mortality using a high resolution aerial image mosaic in the Linville River Gorge, Southern Appalachians, western North Carolina. Our study objectives were: 1) to detect dead trees within the Lower Linville River watershed; 2) to estimate the area occupied by dead trees in the forest canopy surface; 3) to investigate the relationship of dead hemlocks and topography; and 4) to define the spatial pattern of the dead trees. We found ca. 10,000 dead trees within the study area, occupying over 7 ha of the canopy surface with an average area of $36 \mathrm{~m}^{2}$ per dead tree. The density of the dead trees was higher in proximity to the Linville River, at higher elevations, and on northern and northwestern aspects. Spatial pattern of the dead trees was generally clustered at all spatial scales. We suggest that although the reduction in plant biomass resulting from herbivory within the landscapes is modest, impact of the clustered distribution of hemlock mortality, especially in the riparian zones, is noteworthy. Our analysis of the pattern of hemlock decline provides new means for projecting future impacts of HWA on the range of hemlock distribution in eastern North America. 


\title{
Keywords
}

\author{
Adelges Tsugae, Eastern Hemlock, Southern Appalachians, Spatial pattern, Topography, \\ Tree Mortality, Tsuga
}

\section{Introduction}

Biological invasions are one of the greatest environmental challenges of today (Dix et al. 2010). Monitoring and minimizing the impacts of damage by invasive pest insects has become a central issue in the field of forest research (Pimentel et al. 2005; Dukes et al. 2009). The hemlock woolly adelgid (Adelges tsugae Annand, HWA) (Hemiptera: Adelgidae) is currently causing severe decline in vitality and survival of eastern hemlock (Tsuga canadensis L. Carr.) (Pinaceae) and Carolina hemlock (Tsuga caroliniana Engelm.) in eastern North American forests. The HWA, native to East-Asia, is a sap-sucking insect feeding on hemlock parenchyma cells. The ecology of HWA in the eastern USA is well documented (see McClure 1991; Stadler et al. 2006). The initial outbreak in the northeastern USA occurred in the early 1950's (Souto et al. 1996; Orwig et al. 2002). For decades the species has been regarded as a harmless organism (Ward et al. 2004). The populations started to expand from New England during the 1980's (Del Tredici \& Kitajima 2004; Clark et al. 2012). Movement into the Southern Appalachians is recent (Cheah et al. 2004; Krapfl et al. 2011). Eastern and Carolina hemlocks of all size and age classes are infested. HWA herbivory results in progressive decline in tree health and subsequent mortality, usually within 5 - 15 years (Stadler et al. 2006). Eastern and Carolina hemlocks have shown little or no resistance to HWA (Eschtruth et al. 2006).

Hemlocks are keystone host species that are able to tolerate extreme shade and provide unique multi-layer canopies (Orwig \& Foster 1998; Jonas et al. 2012). Eastern hemlock is one of the principal riparian and cove canopy species in the Southern Appalachians (Brown 2004; Ford \& Vose 2007). Mature hemlocks provide thermal cover and forage for over 120 vertebrate species, including mammals and almost 90 bird species (Ward et al. 2004). Hemlock canopies have a significant impact on biodiversity of fish (Ross et al. 2003), terrestrial arthropods (Rohr et al. 2009; Sackett et al. 2011), aquatic invertebrates (Snyder et al. 2002), and other plant species (Kizlinski et al. 2002; Ellison et al. 2005; Orwig et al. 2012). Hemlocks also have an important role in maintaining stream quality and amplitude of stream flow (Ford \& Vose 2007).

HWA can fundamentally modify forest landscapes by altering ecosystem composition, structure, and function (Ford \& Vose 2007; Ford et al. 2012). Effects at the landscape scale include widespread elimination of hemlocks resulting in a forest structure dominated by broadleaved tree species (Stadler et al. 2006; Clark et al. 2012; Birt et al. 2014). Hemlock elimination can significantly alter microclimatic conditions in forests, such as solar radiation. Due to increased light penetration, less shade-tolerant tree species, such as red maple (Acer rubrum L.) (Aceraceae) and black birch (Betulalenta L.), (Betulaceae) could be established in the disturbance patches (Stadler et al. 2006; Spaulding \& Rieske 2010). The newly generated forest canopy gaps resulting from hemlock elimination could also serve as potential areas for establishment of invasive plant species, such as tree of heaven (Ailanthus altissima Mill.) and mimosa tree (Albizia julibrissin Durazz.) (Webster et al. 2006). Hemlock decline by HWA can lead to significant changes in hydrology (Ford \& Vose 2007), carbon cycling (Albani et al. 2010), nitrogen cycling (Orwig et al. 2008), and decomposition (Cobb 2010).

Landscape topographic characteristics of elevation, slope, and aspect may have a major influence on the spatial pattern of HWA infestations, but this interaction has not been examined (Orwig \& Foster 1998). Topography has been associated with the intensity of outbreaks for several other insect species, including European pine sawfly (Neodiprion sertifer Geoffr.) (Niemelä et al. 1987), Siberian silk moth (Dendrolimus superans sibiricus Tschetw.) (Kharuk et al. 2007), autumnal moth (Epirrita autumnata Borkhausen) (Tenow 1975; Ruohomäki et al. 1997), and larch bud moth (Zeiraphera diniana Guenée) (Baltensweiler et al. 2008).

Development of cost-efficient mapping and monitoring methods for investigating the spatial pattern of impacts of HWA on forest landscapes are needed. Changes in forest canopy, such as tree mortality, are often more visible from a bird's eye view than that on the ground. Remote sensing, including aerial images, can more rapidly produce data for broad, remote, and even inaccessible forest lands at a much lower cost in comparison to ground inventories (Ciesla 2000; Hall et al. 2007; Morgan et al. 2010). Aerial imagery is the most frequently 
used remotely sensed data in the field of forestry (Hall 2003). Modern high resolution aerial images enable assessment even at the individual tree level. According to Wulder et al. (2006), a wide range of forest health monitoring needs can be fulfilled with digital aerial imageries.

The general distribution of HWA has been mapped at state and county levels. However, spatially explicit data on the spatial pattern of HWA infestation is needed for realistic ecological and economic impact assessment (Orwig et al. 2002). These data sets have not been collected, largely because hemlocks occur in forest landscapes often characterized by extreme topographic variation. Traditional forest inventory methods are often impractical. Precise information on hemlock mortality still is needed to evaluate the real impacts of HWA herbivory on forest landscapes. Accordingly, our goal was to investigate spatial pattern and distribution of HWA induced hemlock mortality in the Linville River Gorge, Southern Appalachians, North Carolina. Our study objectives were to: 1) detect dead trees within the Lower Linville River watershed; 2) estimate the area occupied by dead trees in the forest canopy surface; 3 ) investigate the relationship of hemlock mortality and topography; and 4) define the spatial pattern of the tree mortality. Our study demonstrates additional tools in the investigation of broad scale ecological and economic impacts of HWA on forest landscapes and vegetation dynamics.

\section{Material}

\subsection{Study Area}

The study area for this investigation was located in the Lower Linville River watershed of the Grandfather Ranger district (GF) $\left(35^{\circ} 56^{\prime} \mathrm{N}, 81^{\circ} 55^{\prime} \mathrm{W}\right)$, Pisgah National Forest, Southern Appalachian Mountains, western North Carolina, USA (Figure 1). The spatial extent was $60 \mathrm{~km}^{2}$. The Linville Gorge wilderness area covers most of the study area. The majority of the wilderness area has remained unlogged and it is one of the largest old-growth forests in the region. However, the area has been subjected to frequent forest fires (Newell \& Peet 1998; Wim

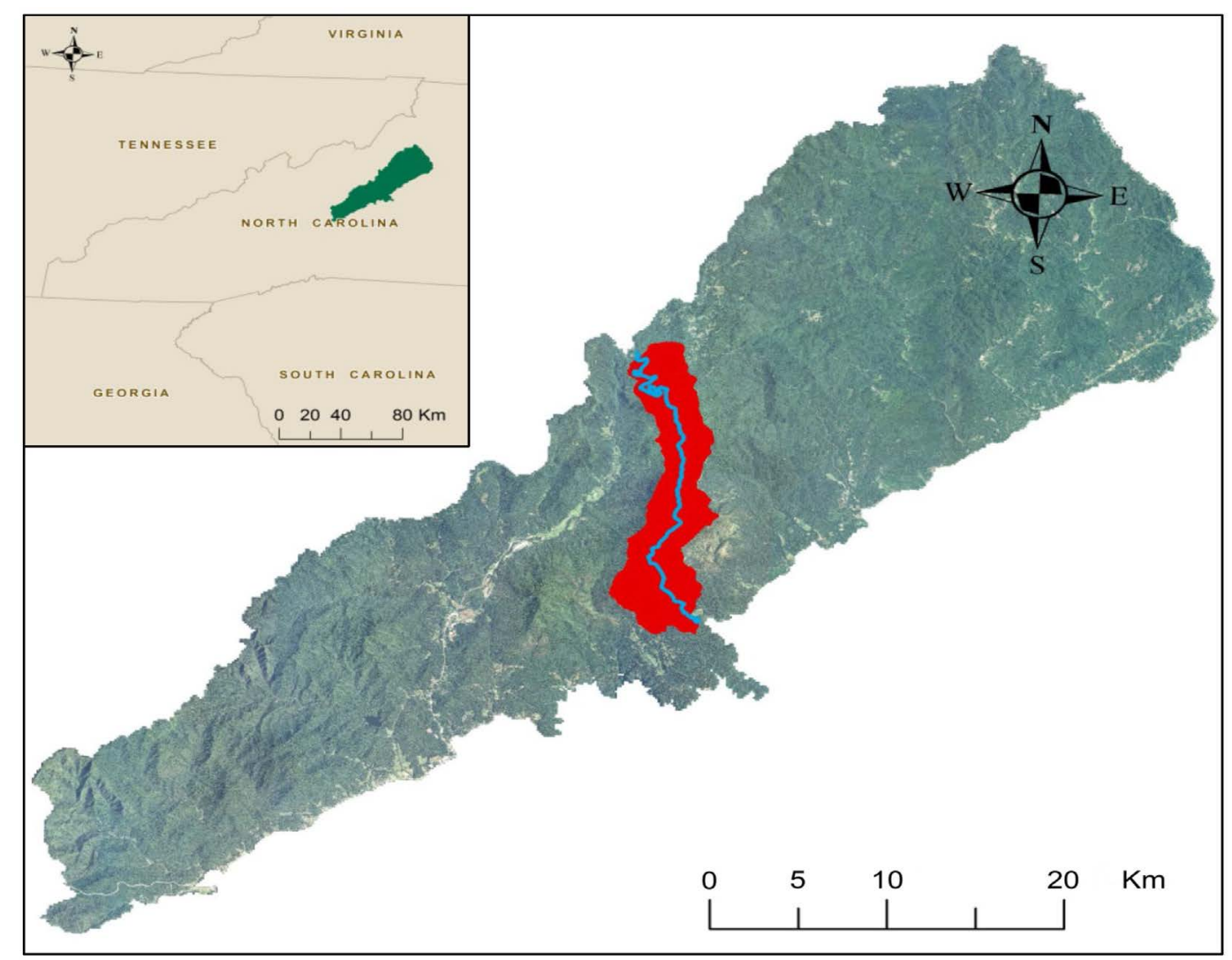

Figure 1. Image mosaic of the Grandfather Ranger district (GF) area with location of the Lower Linville River watershed study area (red) and Linville River (blue) (large image), and location of the GF in western North Carolina (inset upper left corner) $\left({ }^{\circledR}\right.$ Esri map). 
berly \& Reilly 2007). Elevations range from approximately $350 \mathrm{~m}$ above sea level (a.s.l.) at the southern part of the watershed and the bottom of the river basin to $1300 \mathrm{~m}$ a.s.l. on the upper ridges. The topography is very rugged with prominent cliff-like bluffs dividing upper and lower slopes (Wimberly \& Reilly 2007).

The three major ecological zones in the area are Acidic Cove, Xeric Pine-Oak Heath and Oak Heath, and Mesic Oak-Hickory (Simon et al. 2005). The soils are derived from high-grade metamorphosed sedimentary rocks, covered by unconsolidated Quaternary-aged colluvial and alluvial deposits (Lesure et al. 1977; Elliott et al. 2013). The humid temperate climate, diverse topography, and site types provide a variety of habitats suitable for more than 400 vascular plants and a wide diversity of different tree species (Peet et al. 1998; Schafale \& Weakley 1990; Simon et al. 2005). Both eastern and Carolina hemlocks are abundant in the area (Jetton et al. 2008). The HWA was first observed in the area at the early 21th century (Koch et al. 2006).

\subsection{Data Sets}

\subsubsection{Color-infrared Aerial Imagery}

Color-infrared imagery (CIR) with $1 \mathrm{~m}$ spatial resolution was acquired with a Multiple Intergraph Digital Mapping Camera (DMC) system at an altitude of approximately $9000 \mathrm{~m}$ in the summer of 2010 (leaf-on) by the National Agricultural Inventory Program (NAIP). Images were captured simultaneously from four pixel multispectral (MS) cameras with $30 \mathrm{~mm}$ lenses to produce red (R), green (G), blue (B), and near-infrared (NIR) bands. The CIR imagery was used to identify dead trees and estimate canopy surface.

\subsubsection{Color Imagery}

Color (RGB) aerial imagery with $15 \mathrm{~cm}$ spatial resolution with R, G, and B bands was acquired by The Sanborn Map Company Inc. with a large format Zeiss/Intergraph DMC in the winter of 2010 (leaf-off). The flying altitude was of approximately $1500 \mathrm{~m}$ above mean terrain. The RGB imagery was used as a reference in dead tree detection when needed, ensuring that bare ground was not misclassified as dead trees.

\subsubsection{Digital Elevation Model}

Digital elevation model (DEM) by the National Elevation Dataset (NED) was used. NED 3 DEM data sets have a spatial resolution of approximately $3 \mathrm{~m}$ (1/9 arc-seconds) and elevation units in meters. Slope and aspect layers were calculated from the DEM separately.

\section{Methods}

\subsection{Dead Tree Identification and Canopy Surface Area Estimation}

We excluded urban artifacts, such as visible roads, fields and residential areas, deep shadows, and water from the analysis. We digitized these non-forest areas and extracted them from the data sets. The resulting analyzed area was approximately $57 \mathrm{~km}^{2}$. We used a tree-wise approach with visual interpretation of the CIR imagery. The RGB image was used as a reference when needed, e.g., to distinguish dead trees from bare ground. We identified all the visible dead trees within the watershed. In practice, the detected trees were mostly in the upper canopy cover layers. In most cases, dead trees in the suppressed canopy cover layer were not visible.

We took a random sample of $20 \%$ of all the detected dead trees for further analysis. The objective was to estimate the potential gap sizes in the forest canopy surface rather than estimate the tree crown widths. We classified the canopy surface areas and created a distribution with bins of $5 \mathrm{~m}^{2}$ of each class. Our assumption was that the surface area distribution of the sample follows that of the whole dead tree population within the study area. We generalized the area distribution for the entire dead tree population within the study area to estimate the total surface area occupied by the dead trees

\subsection{Topography Related to the Dead Tree Density}

We investigated if elevation, slope, or aspect had an influence on the dead tree density. We derived aspect and slope layers from the DEM raster. The DEM raster was binned to elevation classes by every $100 \mathrm{~m}$ a.s.l., aspects by cardinal and ordinal compass directions, and slopes by every 10 degrees. Coordinates of the dead trees were extracted according to these topographic classes. We calculated densities of the dead trees $\left(\mathrm{n} / \mathrm{km}^{2}\right)$ according to each topography class for elevation, aspect, and slope separately. 
We measured Euclidean distances between all the individual dead trees and the Linville River banks to investigate proportion of the dead trees in the riparian areas. We considered Euclidean distance to better represent the functional grain of HWA regarding its perception of distance in the sharply reliefed landscape of our study area rather than ground distance over the terrain surface. Differences between Euclidean and ground distances vary depending on alteration in topography. We took a subsample of $0.1 \%$ of the trees $(n=99)$ to compare the Euclidean and the ground distances. The distances varied between $9.1 \mathrm{~m}$ and $1304.3 \mathrm{~m}$. Percentage of the differences varied between $0.02 \%$ and $51.9 \%$. However, the mean difference between the Euclidean distance and the ground distance was only $10.1 \%$.

\subsection{Spatial Pattern}

We studied spatial pattern of the dead trees using Ripley's K-function (Ripley 1976, 1977, 1981). Ripley's K-function is a test for deviation from complete spatial randomness (CSR). Ripley's K-function is a second order statistic, based on the distribution of pairs of points. It describes a small-scale spatial correlation structure of a known point pattern and uses information on all inter-point distances (see in more details Goreaud \& Perlissier 2003; Wiegand \& Moloney 2004). The process is essentially the same as counting the number of points in circles of radius $t$ centered on the $n$ points (Dale 1999). With the method, it is possible to compare a point pattern at different scales with point patterns generated by known processes, e.g., a homogenous Poisson process (Bailey \& Gatrell 1995). The Ripley's K-function is detecting only large-scale of clustering (Dale 1999). Ripley's Kfunction describes a pattern over a range of spatial scales, and therefore mixed patterns can also be detected (Wiegand \& Moloney 2004). Ripley's K-function has been used in various forest research applications, including assessment of live tree pattern (Wolf 2005), stand structure (Zenner \& Hibbs 2000; Youngblood et al. 2004), tree mortality (Aakala et al. 2006, 2012), coarse woody debris (Rouvinen et al. 2002), and forest pest monitoring (Kelly \& Meentemeyer 2002; Liu et al. 2007; Lynch \& Moorcroft 2008).

We divided the study area into a grid of subareas, each representing $1 \mathrm{~km}^{2}$ (Figure 2). We clipped the subareas bordering the study area to the perimeter of the watershed to ensure accuracy and avoid errors in the estimation. A minimum of 10 dead trees within a subarea was used as a threshold value for the analysis. We used a linearized square root transformation of the Ripley's K-function; the L-function. The L-function is easier to interpret than the K-function; moreover, the L-function stabilizes the variance and, in this form, under CSR, the L-function equals zero (Goreaud \& Perlissier 2003). We evaluated the statistical significance with the Monte Carlo simulation, at 95\% confidence level. We compared the observed point patterns with Monte Carlo envelopes from 100 simulations of CSR of the same dimensions as the observed subareas (Haase 1995; Wiegand \& Moloney 2004). We analyzed the pattern for spatial scales of $1 \mathrm{~m}$ to $250 \mathrm{~m}$ with intervals of $1.0 \mathrm{~m}$. We used the R statistical computing environment (The R Project 2013), Spatstat library (Baddeley \& Turner 2005), and Translation correction (Ohser 1983) in the implementation.

\section{Results}

\subsection{Dead Tree Identification and Canopy Surface Area Estimation}

We detected and located a total of 9881 dead trees within the watershed. The majority of the dead trees were found in the northern half of the study area and relatively close to the Linville River (Figure 3(a)). We digitized a canopy surface area for 1977 individual dead trees (20\%). The classified canopy surface areas ranged from 3 $\mathrm{m}^{2}$ to $88 \mathrm{~m}^{2}$ with a mean area of $36 \mathrm{~m}^{2}$. The dead trees occupied 7.2 ha of the forest canopy, corresponding $0.1 \%$ of the study area. The frequency distribution was positively skewed, indicating scarcity of detected small dead trees in the population (Figure 3(b)).

\subsection{Topography related to Dead Tree Density}

There is a sharp difference of approximately $1000 \mathrm{~m}$ in elevation between the southern and northern sections of the study area. The slope angle in the area varied from flat (0 degrees) to 80 degrees, facing all cardinal and ordinal compass directions (Figure 4). The distribution of dead trees with respect to topographic characteristics (Figure 5(a)) differed from the distribution of available topographic categories in the study area (Figure 5(b)). Densities of dead trees were highest in the elevation classes of $900-1000 \mathrm{~m}$ a.s.l., with 497.0 dead trees $/ \mathrm{km}^{2}$ and 1000.1 - 1100 m a.s.l., with 323.5 dead trees $/ \mathrm{km}^{2}$ (Figure 5(a)). Dead tree densities were also highest on 


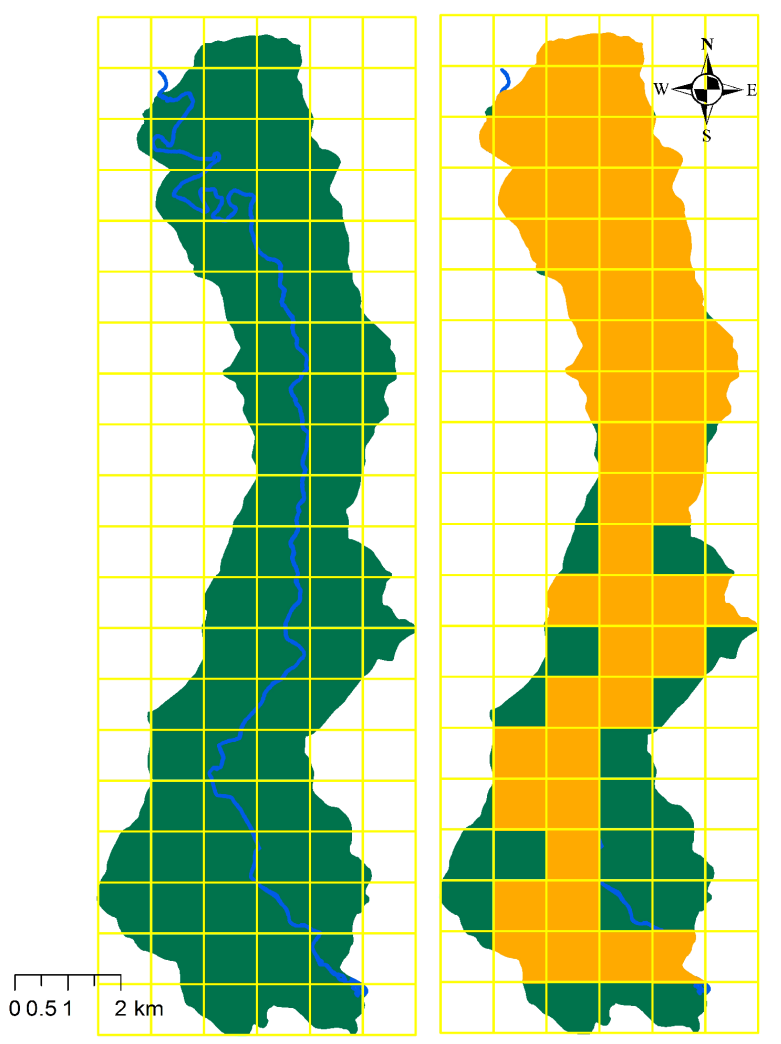

Figure 2. One $\mathrm{km}^{2}$ grid (yellow lines) over the Lower Linville River watershed study area (left) and over the analyzed grid cells (right) Analyzed grid cell subareas (orange) were those having ten or more dead trees.
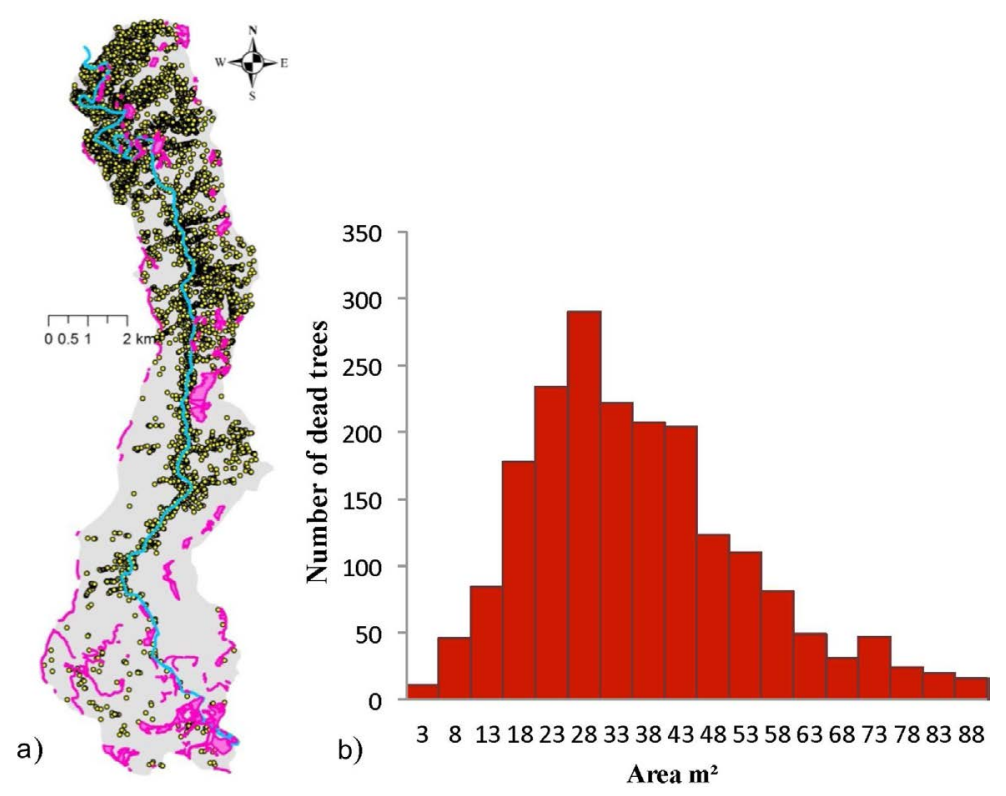

Figure 3. a) Detected dead trees (yellow dots) within the Lower Linville River watershed study area, the Linville River (blue), and the areas excluded from analysis (pink); b) The distribution of canopy surface areas of dead trees. 


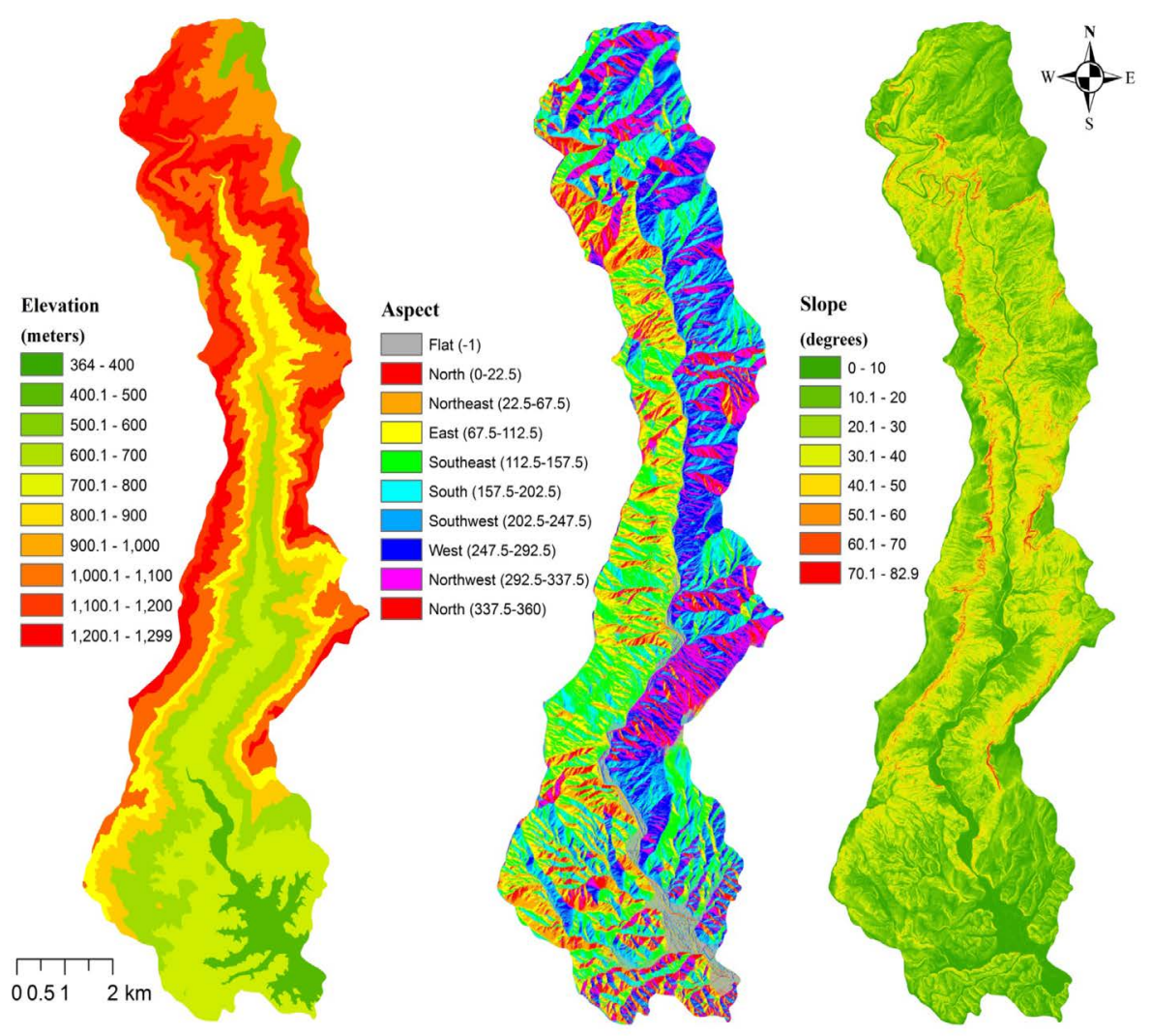

Figure 4. Maps of the Lower Linville River watershed study area showing elevation (left), aspect (middle), and slope angle (right) classes.

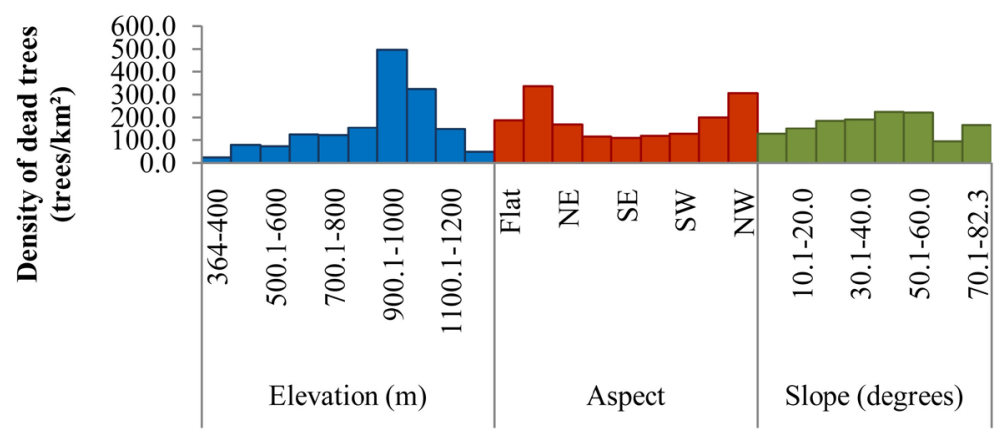

(a)

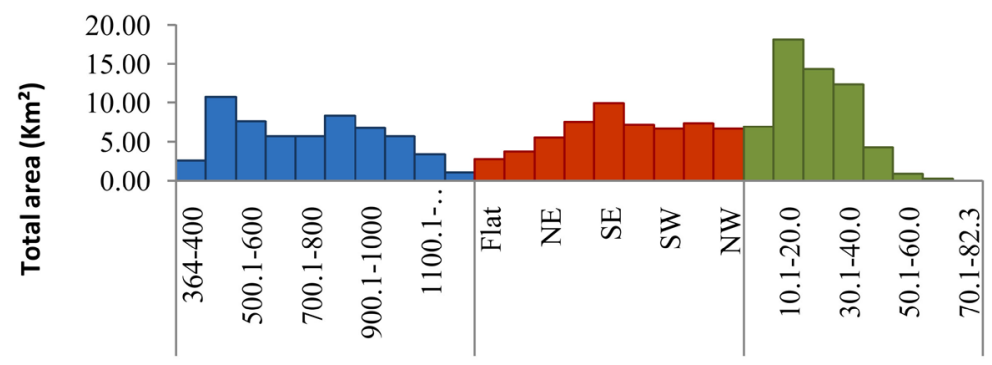

(b)

Figure 5. (a) Densities of the dead trees $\left(\mathrm{n} / \mathrm{km}^{2}\right)$ related to elevation, aspect, and slope and (b) total areas within each class, respectively for the Lower Linville River watershed study area. 
northern and northwestern slopes. There were not distinct differences between slope classes. A mild trend can be observed; dead tree density is slightly increasing along with the slope angle (Figure 5(a)).

Euclidian distances between the dead trees and the Linville River varied between $0 \mathrm{~m}$ and $2760 \mathrm{~m}$. The majority of the dead trees were found relatively close to the Linville River (Figure 6). Twenty five percent of the dead trees were closer than $60 \mathrm{~m}$ from the river banks (Figure 6(b)). Thresholds for $50 \%$ and $75 \%$ of the cumulative distribution were met at the distance to the river of $194 \mathrm{~m}$ and $577 \mathrm{~m}$ respectively (Figure 6(b)).

\subsection{Spatial Pattern}

Density of the dead trees within different subareas varied between 0 and 1192 trees per $\mathrm{km}^{2}$ (Figure 7). We analyzed a total of 54 sub-areas of $1 \mathrm{~km}^{2}$ grid cells. The spatial pattern of dead trees was clustered at all spatial scales from $1 \mathrm{~m}$ to $250 \mathrm{~m}$ in 36 subareas and random in 3 subareas (Figure 7). We detected a mixed spatial pattern of dead trees, varying between random and clustered, in 15 subareas. No dispersed patterns were observed. The pattern of dead trees was clustered at all spatial scales, mostly on higher elevations and near the Linville River (Figure 7).

\section{Discussion}

\subsection{Evaluating Hemlock Mortality at a Suitable Scale for Impact Assessment}

Landscape scale spatially explicit patterns in hemlock decline from HWA have not been studied, and the magnitude of their importance is unknown. Herein, we use the term landscape scale to mean a broad spatial extent (Coulson \& Tchakerian 2010). Three approaches have been used previously to investigate the impact of HWA herbivory on hemlocks: plot data within stands, FIA plot data, and remotely sensed data. Each approach is examined below.

Plot- and stand-wise hemlock mortality between 0\% and 95\% from HWA has been observed (Orwig \& Foster 1998; Paradis et al. 2008). In the Southern Appalachians, Elliott \& Vose (2011) found that in less than three years of HWA infestation, mortality of eastern hemlock was less than $1 \%$ in the Coweeta Basin of western North Carolina. During the following three years, hemlock mortality increased to 33.1\%. Krapfl et al. (2011) found that the mortality of the overstory hemlocks was $11 \%$ on 32 sampling plots in the Great Smokey Mountains of the Tennessee/North Carolina border. Krapfl et al. (2011) suggested that extreme drought in 2007 and 2008 may also affected the hemlock mortality. These studies report important and detailed discoveries on the relation of HWA herbivory and hemlock mortality at a fine scale (small spatial extent). However, a landscape-level analysis of hemlock mortality in the Southern Appalachian forest is lacking.

The current USDA Forest Service Forest Inventory and Analysis (FIA) sampling scheme is based on hexagons of approximately 2500 ha, having at least one 0.4 ha permanent plot within each hexagon (Woudenberg 2010). This FIA scheme was initiated in 1998. Trotter et al. (2013) used the FIA database to address hemlock
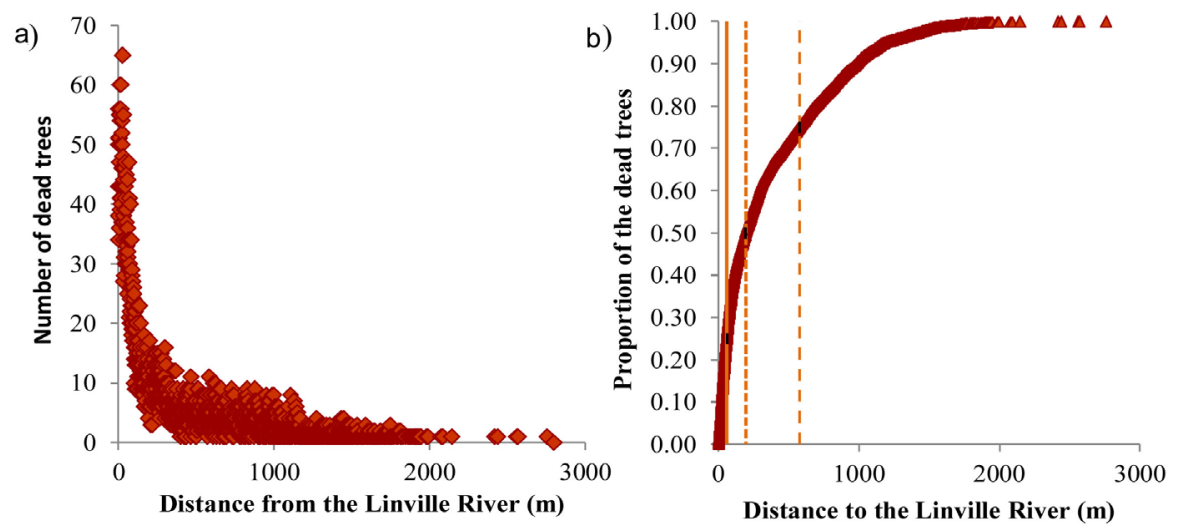

Figure 6. a) Frequencies of the dead trees related to the distance to the Linville River in the Lower Linville River watershed study area. b) A cumulative distribution of the distances. Orange lines represent the threshold distances of 25\% (60 m), 50\% (194 m), and 75\% (577 m) of the cumulative distribution. 


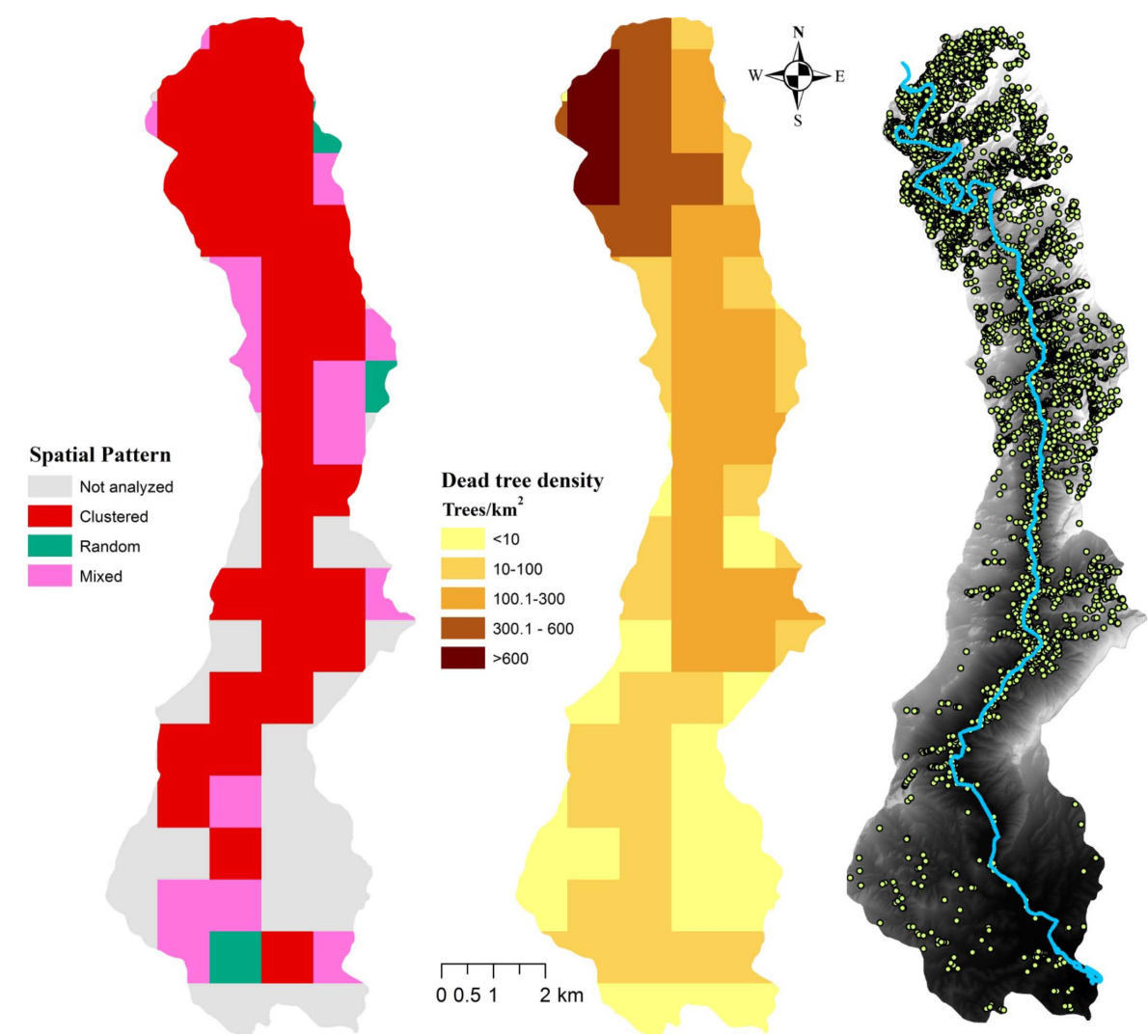

Figure 7. Maps of the Lower Linville River watershed study area study area showing spatial pattern of the dead trees within the analyzed grid cell subareas (left), the dead tree density (middle), and the reference point pattern of dead trees (right).

abundance and change in the eastern USA. They found that basal area of both living and dead hemlocks increased during a 20-year study period at county- and state-levels. They did not find a significant difference between infested and un-infested counties. Trotter et al. (2013) suggested that although many previous studies show substantial negative within-stand impacts of HWA, at the regional level the effects are not evident. Accuracy of the FIA sampling is suitable for national forest inventory purposes and large region inventories. The plot design is not suitable for evaluating HWA impact at the landscape scale.

Emphasis of remote sensing applications on evaluation of impacts of HWA has been based on low-resolution satellite images. Landsat Thematic Mapper (TM) has been the most utilized remote sensing data source (Bonneau et al. 1999; Royle \& Lathorp 2002; Wimberly \& Reilly 2007; Kong et al. 2008). However, hemlock and hemlock mortality mapping via lower resolution data sets has limitations (Koch et al. 2005). Hemlocks typically grow in isolated canopies, distributed throughout landscapes as mixed species that generally also include other conifers. Distinguishing the other conifer species from hemlocks is difficult (Royle \& Lathorp 1997; Orwig et al. 2002; Koch et al. 2005). Therefore high resolution remote sensing applications are needed to map this scattered and clustered phenomenon. The high resolution imagery used in this study provides a means for interpreting ecological impact in the context of landscape heterogeneity (Coulson \& Tchakerian 2010).

\subsection{Topography Related to HWA Induced Hemlock Mortality}

We located almost 10,000 dead trees within the Lower Linville River watershed. Our results indicated that most of the dead trees could be found in proximity of the Linville River. Density of the dead trees was highest on northern and northwestern aspects. In contrast to the distribution of the living hemlocks in the Coweeta Basin, dead hemlocks in our study area were most abundant at higher elevations. This pattern was similar to that observed in Japan, where hemlocks outside their normal range of distribution were more vulnerable to scale insects (McClure 1985). In addition to sap-sucking insects, topography has been observed to influence the distribution 
of other forest insects and their host trees (Niemelä et al. 1987; Ruohomäki et al. 1997; Kharuk et al. 2007; Baltensweiler et al. 2008).

Orwig et al. (2002) studied the landscape pattern of hemlock decline in the central Connecticut, and Narayanaraj et al. (2010) examined the influence of terrain and landform on living eastern hemlocks in the Coweeta Basin, North Carolina. Orwig et al. (2002) observed that a large number of stands were located on ridge tops, steep hillsides, and narrow valleys, which was in accordance to our findings. Forty-six percent of the stands were located on western or northwestern slopes, and $31 \%$ on north or northeastern slopes. The HWA was present on $90 \%$ of their sampling plots. The mean overstory hemlock mortality varied between $0 \%$ on the south facing slopes and $45 \%$ on the west facing slopes, which was similar to our results. Correlation with aspect was weak. Narayanaraj et al. (2010) discovered that the living hemlocks were more abundant close to streams, on flat or gentle slopes, and at lower elevations. They did not find any relationship between hemlock abundance and aspect.

A variety of factors affect species distribution, composition, and abundance (Hodkinson 2005). If the terrain characteristics are well known, vegetation composition and structure could be predicted via species-terrain relationships (Narayanaraj et al. 2010). In the case of HWA induced hemlock mortality, the interactions among topography and tree mortality are complex. Variables, such as solar radiation, mean and maximum air and soil temperatures, vapor pressure deficit, etc. greatly affect the microclimatic habitat conditions for the insect. The effects of this variation are mostly related to change in elevation (Narayanaraj et al. 2010). In addition, Orwig et al. (2002) found that the mortality was correlated strongly with latitude, which could explain the contrasting results regarding aspect in Connecticut and North Carolina. The short infestation history of HWA in the Southern Appalachians might be a critical factor affecting the dynamics of herbivory.

\subsection{Pattern of HWA Herbivory in Forest Landscapes}

We found that the dead trees were clustered in most parts of the study area. Out of 54 analyzed sub-areas, 36 exhibited clustered tree mortality at all studied spatial scales from $1 \mathrm{~m}$ to $250 \mathrm{~m}$. The spatial pattern was random within the three sub-areas at every spatial scale. In 15 sub-areas, the spatial pattern was mixed, varying between random and clustered. In most cases, sub-areas with a random or mixed pattern had small numbers of dead trees. A small sample size widens the confidence envelopes which can result in a random pattern (Buckland 1984). Plot-wise analysis in Connecticut indicated spatially patchy within-stand mortality (Orwig et al. 2002).

We found a wide variation in potential forest gap sizes from individual dead trees $\left(3 \mathrm{~m}^{2}-88 \mathrm{~m}^{2}\right.$ of a class mean), occupying an estimated total of over seven ha of the forest canopy surface ( $0.1 \%$ of the canopy surface). The distribution was positively skewed (Figure 3). This result could be due to hidden smaller dead trees in the understory that are not visible in the imagery. Furthermore, the forests in the study site are mostly mature and this area has not been logged. The pattern of hemlock mortality may be related to canopy cover layers. In a study conducted in the Great Smokey Mountains, Krapfl et al. (2011) found greater HWA caused mortality in understory hemlocks in contrast to trees growing in the upper canopy layers. Orwig \& Foster (1998) found that the mortality was highest among overtopped and intermediate hemlocks within the sampling plots on moderately damaged forest stands in Connecticut. They suggested that the smaller trees exhibited higher mortality rate due to less extensive root systems, higher root competition, lower stem capacitance, and insufficient carbohydrate reserves.

\subsection{Impact of Hemlock Removal from the Southern Appalachian Landscapes}

At the landscape scale, the impact of HWA induced mortality is noteworthy, especially in the riparian areas. Clusters of dead hemlocks may have greater impact on ecosystem structure and function than more scattered individual dead trees. Furthermore, hemlocks serve as foundation (keystone) species in the Southern Appalachian forests. Removal of them from the landscape has a greater ecological impact than would be suggested by biomass alone. Dead hemlocks were most abundant near the Linville River. Clusters of dead trees along the riparian area will affect the vegetation community and structure. According to Ross et al. (2003) and Ford \& Vose (2007), the stream environments are substantially affected by the hemlock decline. For example, broadleaved tree species replacing eastern hemlocks may increase winter insolation and thereby change stream temperatures, water yields, and event timing (Ross et al. 2003; Ford \& Vose 2007; Narayanaraj et al. 2010).

The hemlock decline can lead to more heterogeneous landscapes. Nuckolls et al. (2009) proposed that hem- 
locks would either be replaced by mixed early successional tree species such as red maple, black birch, and yellow poplar (Liriodendron tulipifera L.), or with shrubs like great rhododendron (Rhododendron maximum L.). Birt et al. (2014) simulated long-term impacts on forest landscapes after hemlock removal. They found that the succession without hemlocks leads to an increased proportion of shade intolerant species. They also found out that temporal fluctuation of tree species composition will be more pronounced after hemlock elimination.

Hemlock decline has been compared to the ecological impact of chestnut blight (Cryphonectria parasitica (Murrill) Barr.) on American chestnuts (Castanea dentata (Marsh.) Borkh.) between 1900 and 1940. Day \& Monk (1974) studied changes in species composition following chestnut mortality in a Southern Appalachian watershed. They found that in most cases, chestnuts were replaced by multiple tree species, rather than a single co-dominant species. They also suggested that these large-scale (large area) disturbances might also allow native invasive species such as great rhododendron and mountain laurel (Kalmia latifolia L.) to establish. The HWA also causes severe economic losses (Moore 2008; Holmes et al. 2009). Aukema et al. (2011) estimated that the total annual economic costs by HWA to be over $\$ 200$ million. Losses exclusively to residential property due to dead and dying hemlock can reach up to $\$ 8000$ per ha (Holmes et al. 2009).

We could not distinguish dead hemlocks from other tree species due to similar spectral reflectance. A portion of the dead trees in the study area could have been other tree species. The risk of misidentification was especially high in the southern part of the study area, where the dead tree distribution was coarse and random. However, HWA is currently the most important damaging agent in the Linville River Gorge. The southern pine beetle (Dendroctonus frontalis Zimm., SPB) (Coleoptera: Scolytidae) was earlier a major pest in the area (Xi et al. 2009). Knebel \& Wentworth (2007) studied influence of fire and SPB in the Linville River Gorge area between 1992 and 2001. During this period, both basal area and density of pines on their plots were decreased.

\section{Conclusion}

Hemlock mortality resulting from HWA herbivory will fundamentally change the forest vegetation composition of eastern North American forest landscapes. Evaluating the ecological and economic impact requires precise and accurate estimation of hemlock mortality. Previous studies using plot-wise sampling designs or low-resolution imageries offer valuable insights into hemlock mortality resulting from HWA herbivory. However, these approaches do not provide spatially explicit mortality estimates at appropriate spatial scale needed to evaluate ecological and economic impact in forest landscapes. Our study contributes new insights on spatial pattern and distribution of hemlock mortality at a suitable larger scale and fine resolution. The high resolution imagery used in this study provides means for interpreting ecological impact in the context of landscape functional heterogeneity, i.e., how other living organisms are affected by the removal of hemlock as a component of the forest vegetation community. The reduction in plant biomass within the landscape resulting from herbivory is modest. As foundation species, hemlocks play a variety of functional roles in forest landscapes, ranging from modulating environmental conditions to provision of food and habitat resources for wildlife. The clustered distribution of dead hemlocks, particularly in riparian zones, serves to amplify the impact of HWA herbivory on the forest landscape. Knowledge of the pattern and distribution of hemlock decline provides new means for projecting future impacts of HWA on the range of hemlock distribution in the eastern North America.

\section{Acknowledgements}

This study was made possible by financial aid from Graduate School in Forest Sciences (GSForest), Finnish Academy project "Centre of Excellence in Laser Scanning Research" (CoE-LaSR, decision number 272195), and by the US Forest Service through USDA Forest Service cooperative agreement SRS-12-CA-11330129-077. We thank Dr. Risto Jalkanen for providing helpful insights.

\section{References}

Aakala, T., Fraver, S., Palik, B. J., \& D’Amato, A. W. (2012) Spatially Random Mortality in Old-Growth Red Pine Forests of Northern Minnesota. Canadian Journal of Forest Research, 42, 899-907. http://dx.doi.org/10.1139/x2012-044

Aakala, T., Kuuluvainen, T., Grandpré, L. D., \& Gauthier, S. (2006). Trees Dying Standing in the Northeastern Boreal Old-Growth Forests of Quebec: Spatial Patterns, Rates, and Temporal Variation. Canadian Journal of Forest research, 37, 50-61. http://dx.doi.org/10.1139/x06-201

Albani, M., Moorcroft, P. R., Ellison, A. M., Orwig, D. A., \& Foster, D. R. (2010). Predicting the Impact of Hemlock Wool- 
ly Adelgid on Carbon Dynamics of Eastern United States forests. Canadian Journal of Forest Research, 40, 119-133. http://dx.doi.org/10.1139/X09-167

Aukema, J. E., Leung, B., Kovacs, K., Chivers, C., Britton, K. O., Englin, J. et al. (2011). Economic Impacts of Non-Native Forest Insects in the Continental United States. PLoS One, 6. http://dx.doi.org/10.1371/journal.pone.0024587

Baddeley, A., \& Turner, R. (2005) Spatstat: An R Package for Analyzing Spatial Point Patterns. Journal of Statistical Software, 12, 1-42. www.jstatsoft.org

Bailey, T. C., \& Gatrell, A. C. (1995). Interactive Spatial Data Analysis 413. Essex: Longman Scientific \& Technical.

Baltensweiler, W., Weber, U. M., \& Cherubini, P. (2008). Tracing the Influence of Larch-Bud-Moth Insect Outbreaks and Weather Conditions on Larch Tree-Ring Growth in Engadine (Switzerland). Oikos, 117, 161-172. http://dx.doi.org/10.1111/j.2007.0030-1299.16117.x

Birt, A. G., Zeng, Y., Tchakerian, M. D., Coulson, R. N., Lafon, D. M., Cairns, D. M. et al. (2014). Evaluating Southern Appalachians Forest Dynamics without Eastern Hemlock: Consequence of Herbivory by the Hemlock Woolly Adelgid. Open Journal of Forestry, 4, 91-98. http://dx.doi.org/10.4236/ojf.2014.42014

Bonneau, L. R., Shields, K. S., \& Civco, D. L. (1999). Using Satellite Images to Classify and Analyze the Health of Hemlock Forests Infested by the Hemlock Woolly Adelgid. Biological Invasions, 1, 255-267. http://dx.doi.org/10.1023/A:1010021629127

Brown, K. (2004). Growth and Nutritional Responses of Western Hemlock to Fertilization: A Review. Journal of Ecosystems and Management, 3, 1-15.

Buckland, S. T. (1984). Monte Carlo Confidence Intervals. Biometrics, 40, 811-817. http://dx.doi.org/10.2307/2530926

Cheah, C., Montgomery, M. E., Salom, S., Parker, B. I., \& Skinner, M. (2004). Biological Control of Hemlock Woolly Adelgid. Morgantown, WV: US Department of Agriculture, Forest Service, FHTET, 28.

Ciesla, W. (2000). Remote Sensing in Forest Health Protection. Fort Collins, CO: USDA Forest Service Remote Sensing Applications Center Salt Lake City, UT and FHTET, 276.

Clark, J. T., Fei, S., Liang, L., \& Rieske, L. K. (2012). Mapping Eastern Hemlock: Comparing Classification Techniques to Evaluate Susceptibility of a Fragmented and Valued Resource to an Exotic Invader, the Hemlock Woolly Adelgid. Forest Ecology and Management, 266, 216-222. http://dx.doi.org/10.1016/j.foreco.2011.11.030

Cobb, R. C. (2010). Species Shift Drives Decomposition Rates Following Invasion by Hemlock Woolly Adelgid. Oikos, 119, 1291-1298. http://dx.doi.org/10.1111/j.1600-0706.2009.18308.x

Coulson, R. N., \& Tchakerian, M. D. (2010). Basic Landscape Ecology. Boston, MA: KEL Partners Incorporated, 300.

Dale, M. R. (1999). Spatial Pattern Analysis in Plant Ecology. Ecology, 88, 366-370.

Day, F. P., \& Monk, C. D. (1974). Vegetation Patterns on a Southern Appalachian Watershed. Ecology, 55, 1064-1074. http://dx.doi.org/10.2307/1940356

Del Tredici, P., \& Kitajima, A. (2004). Introduction and Cultivation of Chinese Hemlock (Tsuga chinensis) and Its Resistance to Hemlock Woolly Adelgid (Adelges tsugae). Journal of Arboriculture, 30, 282-287.

Dix, M. E., Buford, M., Slavicek, J., Solomon, A. M., \& Conrad, S. G. (2010). Invasive Species and Disturbances: Current and Future Roles of Forest Service Research and Development. In M. E. Dix, \& K. O. Britton (Eds.), A Dynamic Invasive Species Research Vision: Opportunities and Priorities 2009-2029 (pp. 91-102). Washington DC: USDA Forest Service, Research and Development.

Dukes, J. S., Pontius, J., Orwig, D., Garnas, J. R., Rodgers, V. L., Brazee, N. et al. (2009). Responses of Insect Pests, Pathogens and Invasive Plant Species to Climate Change in the Forests of Northeastern North America: What Can We Predict? Canadian Journal of Forest Research, 39, 231-248. http://dx.doi.org/10.1139/X08-171

Elliott, K. J., Knoepp, J. D., Vose, J. M., \& Jackson, W. A. (2013). Interacting Effects of Wildfire Severity and Liming on Nutrient Cycling in a Southern Appalachian Wilderness Area. Plant and Soil, 366, 165-183. http://dx.doi.org/10.1007/s11104-012-1416-z

Elliott, K. J., \& Vose, J. M. (2011). The Contribution of the Coweeta Hydrologic Laboratory to Developing an Understanding of Long-Term (1934-2008) Changes in Managed and Unmanaged Forests. Forest Ecology and Management, 261, 900-910. http://dx.doi.org/10.1016/j.foreco.2010.03.010

Ellison, A. M., Bank, M. S., Clinton, B. D., Colburn, E. A., Elliott, K., Ford, C. R. et al. (2005). Loss of Foundation Species: Consequences for the Structure and Dynamics of Forested Ecosystems. Frontiers in Ecology and the Environment, 3, 479486. http://dx.doi.org/10.1890/1540-9295(2005)003[0479:LOFSCF]2.0.CO;2

Eschtruth, A. K., Cleavitt, N. L., Battles, J. J., Evans, R. A., \& Fahey, T. J. (2006). Vegetation Dynamics in Declining Eastern Hemlock Stands: 9 Years of Forest Response to Hemlock Woolly Adelgid Infestation. Canadian Journal of Forest Research, 36, 1435-1450. http://dx.doi.org/10.1139/x06-050 
Ford, C. R., \& Vose, J. M. (2007). Tsuga canadensis (L.) Carr. Mortality Will Impact Hydrologic Processes in Southern Appalachian Forest Ecosystems. Ecological Applications, 17, 1156-1167. http://dx.doi.org/10.1890/06-0027

Ford, C. R., Elliot, K. J., Clinton, B. D., Kloeppel, B. D., \& Vose, J. M. (2012). Forest Dynamics Following Eastern Hemlock Mortality in the Southern Appalachians. Oikos, 121, 523-536. http://dx.doi.org/10.1111/j.1600-0706.2011.19622.x

Goreaud, F., \& Pélissier, R. (2003). Avoiding Misinterpretation of Biotic Interactions with the Intertype K12-Function: Population Independence vs. Random Labeling Hypotheses. Journal of Vegetation Science, 14, 681-692.

Haase, P. (1995). Spatial Pattern Analysis in Ecology Based on Ripley’s K-Function: Introduction and Methods of Edge Correction. Journal of Vegetation Science, 6, 575-582. http://dx.doi.org/10.2307/3236356

Hall, R. J., Fernandes, R. A., Hogg, E. H., Brandt, J. P., Butson, C., Case, B. S., \& Leblanc, S. G. (2003). Relating Aspen Defoliation to Changes in Leaf Area Derived from Field and Satellite Remote Sensing Data. Canadian Journal of Remote Sensing, 29, 299-313. http://dx.doi.org/10.5589/m03-001

Hall, R. J., Skakun, R. S., \& Arsenault, E. J. (2007). Remotely Sensed Data in the Mapping of Insect Defoliation. In M. A. Wulder, \& S. E. Franklin (Eds.), Understanding Forest Disturbance and Spatial Pattern. Remote Sensing and GIS Approaches (pp. 85-111). Boca Raton, FL: CRC Press, Taylor and Francis Group.

Hodkinson, I. D. (2005). Terrestrial Insects along Elevation Gradients: Species and Community Responses to Altitude. Biological Reviews, 80, 489-513. http://dx.doi.org/10.1017/S1464793105006767

Holmes, T. P., Aukema, J. E., Von Holle, B., Liebhold, A., \& Sills, E. (2009). Economic Impacts of Invasive Species in Forests. Annals of the New York Academy of Sciences, 1162, 18-38. http://dx.doi.org/10.1111/j.1749-6632.2009.04446.x

Jetton, R. M., Dvorak, W. S., \& Whittier, W. A. (2008). Ecological and Genetic Factors That Define the Natural Distribution of Carolina Hemlock in the Southeastern United States and Their Role in ex Situ Conservation. Forest Ecology and Management, 255, 3212-3221. http://dx.doi.org/10.1016/j.foreco.2008.01.032

Jonas, S., Xi, W., Waldron, J., \& Coulson, R. (2012). Ecological Considerations for Forest Restoration Following Hemlock Woolly Adelgid Outbreaks. Tree and Forestry Science and Biotechnology, 6, 22-26.

Kelly, M., \& Meentemeyer, R. K. (2002). Landscape Dynamics of the Spread of Sudden Oak Death. Photogrammetric Engineering and Remote Sensing, 68, 1001-1010.

Kizlinski, M. L., Orwig, D. A., Cobb, R. C., \& Foster, D. R. (2002). Direct and Indirect Ecosystem Consequences of an Invasive Pest on Forests Dominated by Eastern Hemlock. Journal of Biogeography, 29, 1489-1503. http://dx.doi.org/10.1046/j.1365-2699.2002.00766.x

Knebel, L., \& Wentworth, T. R. (2007). Influence of Fire and Southern Pine Beetle on Pine-Dominated Forests in the Linville Gorge Wilderness, North Carolina. Castanea, 72, 214-225. http://dx.doi.org/10.2179/06-18.1

Koch, F. H., Cheshire, H. M., \& Devine, H. A. (2006). Landscape-Scale Prediction of Hemlock Woolly Adelgid, Adelges tsugae (Homoptera: Adelgidae), Infestation in the Southern Appalachian Mountains. Environmental Entomology, 35, 1313-1323. http://dx.doi.org/10.1603/0046-225X(2006)35[1313:LPOHWA]2.0.CO;2

Koch, F. H., Cheshire, H. M., \& Devine, H. A. (2005). Mapping Hemlocks via Tree-Based Classification of Satellite Imagery and Environmental Data. Morgantown, WV: US Department of Agriculture, Forest Service, FHTET-2005-01, 11.

Kong, N., Fei, S., Rieske-Kinney, L., \& Obrichy, J. (2008). Mapping Hemlock Forest in Harlan County, Kentucky. In P. Bettinger, K. Merry, S. Fei, J. Drake, N. Nibbelink, \& J. Hepinstall (Eds.), Proceedings of the 6th Southern Forestry and Natural Resources GIS Conference (pp. 107-117). Athens: Warnell School of Forestry and Natural Resources, University of Georgia.

Krapfl, K. J., Holzmueller, E. J., \& Jenkins, M. A. (2011). Early Impacts of Hemlock Woolly Adelgid in Tsuga Canadensis Forest Communities of the Southern Appalachian Mountains. Journal of the Torrey Botanical Society, 138, 93-106. http://dx.doi.org/10.3159/10-RA-031.1

Lesure, F. G. (1977). Mineral Resources of the Joyce Kilmer-Slickrock Wilderness, North Carolina-Tennessee. Washington DC: United States Government Printing Office, 89.

Liu, D., Kelly, M., Gong, P., \& Guo, Q. (2007). Characterizing Spatial-Temporal Tree Mortality Patterns Associated with a New Forest Disease. Forest Ecology and Management, 253, 220-231. http://dx.doi.org/10.1016/j.foreco.2007.07.020

Lynch, H. J., \& Moorcroft, P. R. (2008). A Spatiotemporal Ripley’s K-Function to Analyze Interactions between Spruce Budworm and Fire in British Columbia, Canada. Canadian Journal of Forest Research, 38, 3112-3119. http://dx.doi.org/10.1139/X08-143

McClure, M. S. (1985). Patterns of Abundance, Survivorship and Fecundity of Nuculaspis tsugae (Homoptera: Diapsididae) on Tsuga Species in Japan in Relation to Elevation. Environmental Entomology, 14, 413-415.

McClure, M. S. (1991). Density-Dependent Feedback and Population Cycles in Adelges tsugae (Homoptera: Adelgidae) on Tsugacanadensis. Environmental Entomology, 20, 258-264.

Moore, C. C. (2008). Using Empirical Benefit Estimates in a Bioeconomic Model of Invasive Species Control. Ph.D. Disser- 
tation, Raleigh, NC: Carolina State University.

Morgan, J. L., Gergel, S. E., \& Coops, N. C. (2010). Aerial Photography: A Rapidly Evolving Tool for Ecological Management. BioScience, 60, 47-59. http://dx.doi.org/10.1525/bio.2010.60.1.9

Narayanaraj, G., Bolstad, P.V., Elliott, K. J., \& Vose, J. M. (2010). Terrain and Landform Influence on Tsuga canadensis (L.) Carriere (Eastern Hemlock) Distribution in the Southern Appalachian Mountains. Castanea, 75, 1-18. http://dx.doi.org/10.2179/08-049.1

Newell, C. L., \& Peet, R. K. (1998). Vegetation of Linville Gorge Wilderness, North Carolina. Castanea, 63, $275-322$.

Niemelä, P., Rousi, M., \& Saarenmaa, H. (1987). Topographical Delimitation of Neodiprion sertifer (Hym., Diprionidae) Outbreaks on Scots Pine in Relation to Needle Quality. Journal of Applied Entomology, 103, 84-91.

http://dx.doi.org/10.1111/j.1439-0418.1987.tb00962.x

Nuckolls, A. E., Wurzburger, N., Ford, C. R., Hendrick, R. L., Vose, J. M., \& Kloeppel, B. D. (2009). Hemlock Declines Rapidly with Hemlock Woolly Adelgid Infestation: Impacts on the Carbon Cycle of Southern Appalachian Forests. Ecosystems, 12, 179-190. http://dx.doi.org/10.1007/s10021-008-9215-3

Ohser, J. (1983). On Estimators for the Reduced Second Moment Measure of Point Processes. Series Statistics, 14 , 63-71. http://dx.doi.org/10.1080/02331888308801687

Orwig, D. A., \& Foster, D. R. (1998). Foster Forest Response to the Introduced Hemlock Woolly Adelgid in Southern New England, USA. Journal of Torrey Botanical Society, 125, 60-73. http://dx.doi.org/10.2307/2997232

Orwig, D. A., Cobb, R. C., D’Amato, A. W., Kizlinski, M. L., \& Foster, D. R. (2008). Multi-Year Ecosystem Response to Hemlock Woolly Adelgid Infestation in Southern New England Forests. Canadian Journal of Forest Research, 38, 834843. http://dx.doi.org/10.1139/X07-196

Orwig, D. A., Foster, D. R., \& Mausel, D. L. (2002). Landscape Patterns of Hemlock Decline in New England Due to the Introduced Hemlock Woolly Adelgid. Journal of Biogeography, 29, 1475-1487. http://dx.doi.org/10.1046/j.1365-2699.2002.00765.x

Orwig, D. A., Thompson, J. R., Povak, N. A., Manner, M., Niebyl, D., \& Foster, D. R. (2012). A Foundation Tree at the Precipice: Tsuga canadensis Health after the Arrival of Adelges tsugae in Central New England. Ecosphere, 3, art 10. http://dx.doi.org/10.1890/ES11-0277.1

Paradis, A., Elkinton, J., Hayhoe, K., \& Buonaccorsi, J. (2008). Role of Winter Temperature and Climate Change on the Survival and Future Range Expansion of the Hemlock Woolly Adelgid (Adelges tsugae) in Eastern North America. Mitigation and Adaptation Strategies for Global Change, 13, 541-554. http://dx.doi.org/10.1007/s11027-007-9127-0

Pimentel, D., Zuniga, R., \& Morrison, D. (2005). Update on the Environmental and Economic Costs Associated with AlienInvasive Species in the United States. Ecological Economics, 52, 273-288. http://dx.doi.org/10.1016/j.ecolecon.2004.10.002

Ripley, B. D. (1976). The Second-Order Analysis of Stationary Point Processes. Journal of Applied Probability, 13, 255-266. http://dx.doi.org/10.2307/3212829

Ripley, B. D. (1977). Modeling Spatial Patterns. Journal of the Royal Statistical Society. Series B (Methodological), 39, 172-212.

Ripley, B. D. (1981). Spatial Statistics. New York: Wiley \& Sons, 252. http://dx.doi.org/10.1002/0471725218

Rohr, J. R., Mahan, C. G., \& Kim, K. C. (2009). Response of Arthropod Biodiversity to Foundation Species Declines: The Case of the Eastern Hemlock. Forest Ecology and Management, 258, 1503-1510. http://dx.doi.org/10.1016/j.foreco.2009.07.002

Ross, R. M., Bennett, R. M., Snyder, C. D., Young, J. A., Smith, D. R., \& Lemarie, D. P. (2003). Influence of Eastern Hemlock (Tsuga canadensis L.) on Fish Community Structure and Function in Headwater Streams of the Delaware River Basin. Ecology of Freshwater Fish, 12, 60-65. http://dx.doi.org/10.1034/j.1600-0633.2003.00006.x

Rouvinen, S., Kuuluvainen, T., \& Karjalainen, L. (2002). Coarse Woody Debris in Old Pinus sylvestris Dominated Forests along a Geographic and Human Impact Gradient in Boreal Fennoscandia. Canadian Journal of Forest Research, 32, 21842200. http://dx.doi.org/10.1139/x02-144

Royle, D. D., \& Lathrop, R. G. (1997). Monitoring Hemlock Forest Health in New Jersey Using Landsat TM Data and Change Detection Techniques. Forest Science, 43, 327-335.

Royle, D. D., \& Lathrop, R. G. (2002). Discriminating Tsugacanadensis Hemlock Forest Defoliation Using Remotely Sensed Change Detection. Journal of Nematology, 34, 213-221.

Ruohomäki, K., Virtanen, T., Kaitaniemi, P., \& Tammaru, T. (1997). Old Mountain Birches at High Altitudes Are Prone to Outbreaks of Epirrita autumnata (Lepidoptera: Geometridae). Environmental Entomology, 26, 1096-1104.

Sackett, T. E., Record, S., Bewick, S., Baiser, B., Sanders, N. J., \& Ellison, A. M. (2011). Response of Macroarthropod Assemblages to the Loss of Hemlock (Tsuga canadensis), a Foundation Species. Ecosphere, 2, art 74. 
http://dx.doi.org/10.1890/ES11-00155.1

Simon, S. A., Collins, T. K., Kauffman, G. L., McNab, W. H., \& Ulrey, C. J. (2005). Ecological Zones in the Southern Appalachians: First Approximation. Research Paper SRS-41, Asheville, NC: USDA Forest Service, Southern Research Station, 41.

Snyder, C. D., Young, J. A., Lemarié, D. P., \& Smith, D. R. (2002). Influence of Eastern Hemlock (Tsuga canadensis) Forests on Aquatic Invertebrate Assemblages in Headwater Streams. Canadian Journal of Fisheries and Aquatic Sciences, 59, 262-275. http://dx.doi.org/10.1139/f02-003

Souto, D., Luther, T., Chianese, B., Salom, S. M., Tigner, T. C., \& Reardon, R. C. (1996). Past and Current Status of HWA in Eastern and Carolina Hemlock Stands. In Proceedings of the First Hemlock Woolly Adelgid Review (pp. 9-15). Charlottesville, VA: FHTET, USDA Forest Service.

Spaulding, H. L., \& Rieske, L. K. (2010). The Aftermath of an Invasion: Structure and Composition of Central Appalachian Hemlock Forests Following Establishment of Hemlock Woolly Adelgid, Adelges tsugae. Biological Invasions, 12, 31353143. http://dx.doi.org/10.1007/s10530-010-9704-0

Stadler, B., Müller, T., \& Orwig, D. (2006). The Ecology of Energy and Nutrient Fluxes in Hemlock Forests Invaded by Hemlock Woolly Adelgid. Ecology, 87, 1792-1804. http://dx.doi.org/10.1890/0012-9658(2006)87[1792:TEOEAN]2.0.CO;2

Tenow, O. (1975). Topographical Dependence of the Outbreak of Oporinia autumnata Bkh. (Lep., Geometridae) in a Mountain Birch Forest in Northern Sweden. Zoon, 3, 85-110.

The R Project for Statistical Computing (2013). http://www.r-project.org/

Trotter III, R. T., Morin, R. S., Oswalt, S. N., \& Liebhold, A. (2013). Changes in the Regional Abundance of Hemlock Associated with the Invasion of Hemlock Woolly Adelgid (Adelges tsugae Annand). Biological Invasions, 15, 2667-2679. http://dx.doi.org/10.1007/s10530-013-0482-3

Ward, J. S., Montgomery, M. E. Cheah, C. J., Onken, B. P., \& Cowles, R. S. (2004). Eastern Hemlock Forests: Guidelines to Minimize the Impacts of Hemlock Woolly Adelgid. Morgantown, WV: USDA Forest Service Northeastern Area State \& Private Forestry, 1-27.

Webster, C. R., Jenkins, M. A., \& Jose, S. (2006). Woody Invaders and the Challenges They Pose to Forest Ecosystems in the Eastern United States. Journal of Forestry, 104, 366-374.

Wiegand, T., \& Moloney, K. (2004). Rings, Circles and Null-Models for Point Pattern Analysis in Ecology. Oikos, 104, 209229. http://dx.doi.org/10.1111/j.0030-1299.2004.12497.x

Wimberly, M. C., \& Reilly, M. J. (2007). Assessment of Fire Severity and Species Diversity in the Southern Appalachians Using Landsat TM and ETM+ Imagery. Remote Sensing of Environment, 108, 189-197. http://dx.doi.org/10.1016/j.rse.2006.03.019

Wolf, A. (2005). Fifty Year Record of Change in Tree Spatial Patterns within a Mixed Deciduous Forest. Forest Ecology and Management, 215, 212-223. http://dx.doi.org/10.1016/j.foreco.2005.05.021

Wulder, M. A., Dymond, C. C., White, J. C., Leckie, D. G., \& Carroll, A. L. (2006). Surveying Mountain Pine Beetle Damage of Forests: A Review of Remote Sensing Opportunities. Forest Ecology and Management, 221, 27-41. http://dx.doi.org/10.1016/j.foreco.2005.09.021

Xi, W. M., Waldron, J. D., Lafon, C. W., Cairns, D. M., Birt, A. G., Tchakerian, M. D., Coulson, R. N., \& Klepzig, K. D. (2009). Modeling Long-Term Effects of Altered Fire Regimes Following Southern Pine Beetle Outbreaks (North Carolina). Ecological Restoration, 27, 24-26. http://dx.doi.org/10.3368/er.27.1.24

Youngblood, A., Max, T., \& Coe, K. (2004). Stand Structure in Eastside Old-Growth Ponderosa Pine Forests of Oregon and Northern California. Forest Ecology and Management, 199, 191-217. http://dx.doi.org/10.1016/j.foreco.2004.05.056

Zenner, E. K., \& Hibbs, D. E. (2000). A New Method for Modeling the Heterogeneity of Forest Structure. Forest Ecology and Management, 129, 75-87. http://dx.doi.org/10.1016/S0378-1127(99)00140-1. 
Scientific Research Publishing (SCIRP) is one of the largest Open Access journal publishers. It is currently publishing more than 200 open access, online, peer-reviewed journals covering a wide range of academic disciplines. SCIRP serves the worldwide academic communities and contributes to the progress and application of science with its publication.

Other selected journals from SCIRP are listed as below. Submit your manuscript to us via either submit@scirp.org or Online Submission Portal.
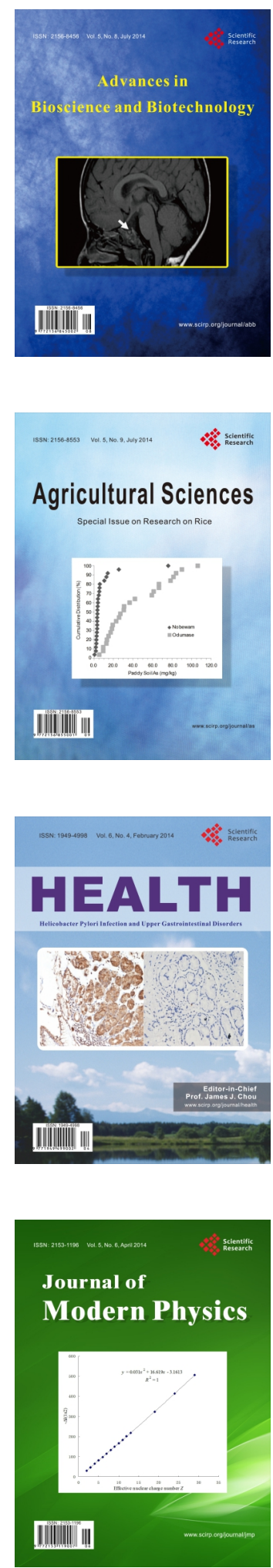
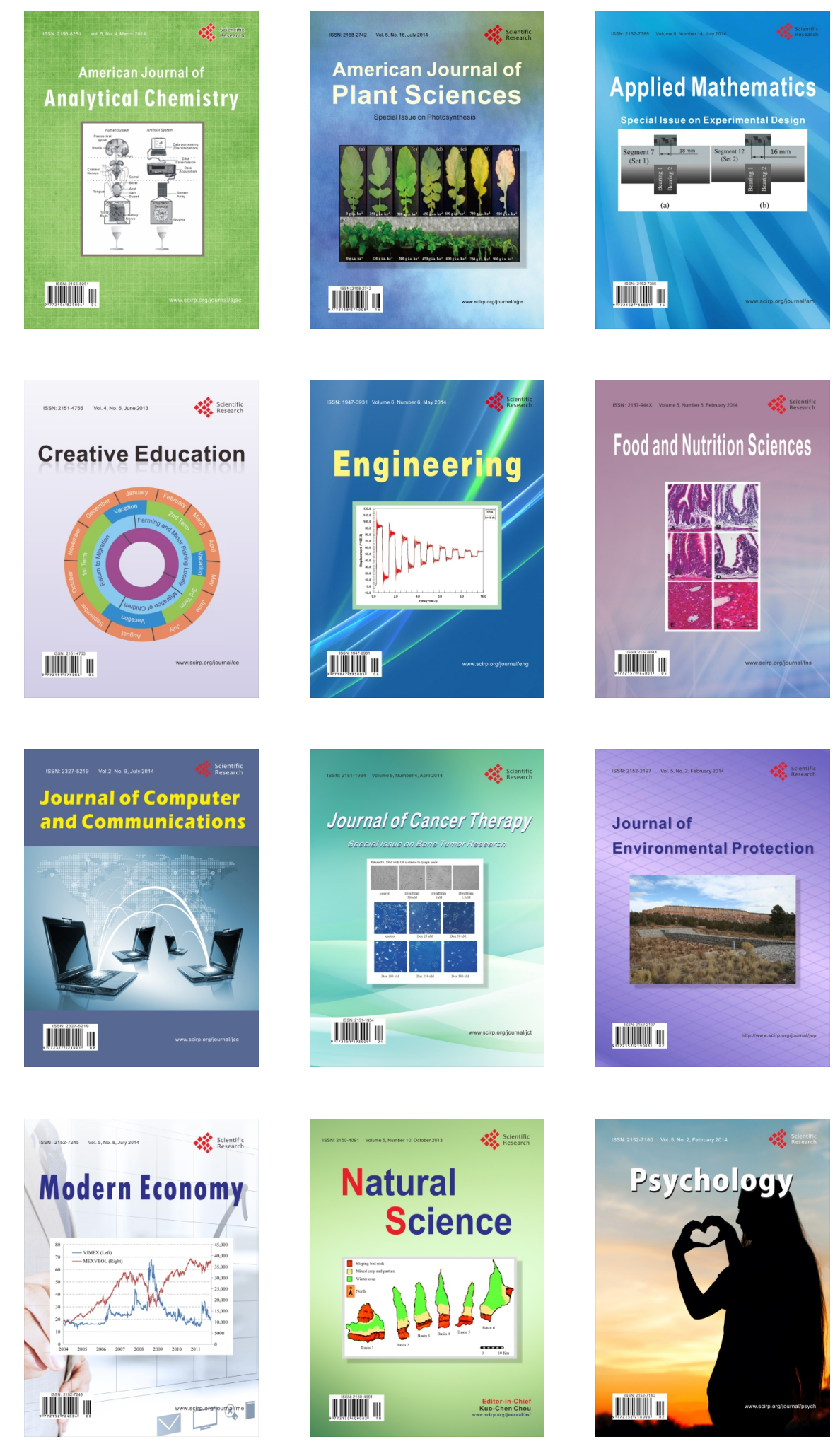